2

3 \section{6} 8 1 5 6

\title{
LASER USES IN NON-CORONARY ARTERIAL DISEASE
}

Jérémie JAYET ${ }^{1,4}$, MD, Raphaël $\operatorname{COSCAS}^{1,2}, \mathrm{MD}, \mathrm{PhD}$, Frédéric $\mathrm{HEIM}^{4,5}, \mathrm{PhD}$, Olivier GOEAU BRISSONIERE, MD, $\mathrm{PhD}^{1}$, Isabelle JAVERLIAT ${ }^{1}$, MD, Nabil CHAKFE ${ }^{3,4}, \mathrm{MD}, \mathrm{PhD}$, Marc COGGIA ${ }^{1}$, MD (1)

${ }^{1}$ Department of Vascular Surgery, Ambroise Paré University Hospital, Assistance Publique - Hôpitaux de Paris (AP-HP), Boulogne-Billancourt, and Faculté de Médecine Paris-Ile de France-Ouest, UFR des sciences de la santé Simone Veil, Université Versailles Saint-Quentin en Yvelines, Montigny-le-Bretonneux, France.

${ }^{2}$ UMR 1018, Inserm-Paris11 - CESP, Versailles Saint-Quentin-en-Yvelines University, Paris-Saclay University, Paul Brousse Hospital, Villejuif, France.

${ }^{3}$ Department of Vascular Surgery and Kidney Transplantation, Hôpitaux Universitaires de Strasbourg, Université de Strasbourg, Strasbourg, France

${ }^{4}$ Groupe Européen de Recherche sur les Prothèses Appliquées à la Chirurgie Vasculaire (GEPROVAS), Strasbourg, France.

${ }^{5}$ Laboratoire de Physique et Mécanique des Textiles, Mulhouse, France 7

Emails: jeremiejayet@gmail.com; rcoscas@gmail.com; frederic.heim@uha.fr; ijaverliat@yahoo.fr; olivier.goeau-brissonniere2@orange.fr; Nabil.Chakfe@chru-strasbourg.fr; mpcoggia@aol.com.

2 Corresponding author: Dr Raphaël Coscas, MD, PhD, Department of Vascular Surgery, Ambroise Paré 3 University Hospital, 9 avenue Charles de Gaulle, 92104 Boulogne Cedex, France. Tel: +33 (0) 1.49.09.55.85; 4 Fax: +33 (0) 1.49.09.53.18; E-mail: rcoscas@gmail.com 


\section{$27 \quad$ ABSTRACT}

28

29 Objectives: In the past decade, excimer laser angioplasty (ELA) has emerged in the field of peripheral atherosclerotic disease (PAD). Laser indications now extend to off-label uses, such as in situ fenestration of aortic endograft. The aim of this study was to review the different therapeutics applications of lasers in arterial disease treatment.

Review Methods: We reviewed the English-language literature using the Preferred Reporting Items for Systematic Reviews and Meta-Analysis (PRISMA) guidelines. We selected 106 relevant papers. We excluded unrelated papers $(n=67)$, letters and commentaries $(n=6)$ and review articles $(n=7)$, leaving 26 articles to form the basis of this review.

Results: A total of 18 articles were included in the analysis of ELA applications in PAD. Nine articles were related to atherosclerotic plaques. With a mean follow-up of $15 \pm 7$ months, primary patency was $65 \% \pm 20 \%$. Mean distal embolism rate during the procedure was 5\%. Eight more articles focused on in-stent restenosis. The mean technical success was $98 \%$, and the rate of distal embolism during the procedure was $9 \%$. With a mean follow-up of $10 \pm 4$ months, primary patency was $68 \% \pm 18 \%$. Eight articles described "off- label" excimer laser indications in endovascular therapy, including five papers regarding in situ fenestrations for complex aortic aneurysms.

44 Conclusion: Laser atherectomy and laser assisted techniques are an important part of a vascular surgeon and interventionalist's armamentarium.

\section{Keywords:}

Excimer Laser, In stent restenosis, Atherosclerotic Plaques, In situ fenestration 


\section{MANUSCRIPT}

55

57

\section{INTRODUCTION}

Since 1960, light amplification by stimulated emission of radiation (laser) has appeared as an applicable energy source for medical use thanks to its unidirectional, pulsatile and monochromatic characteristics. The different physical mechanisms account for the many ways to exploit the capacity of laser technology in medical utilization [1-6]. In this last decade, laser technology has emerged as a new tool in endovascular therapy [7,8]. Lasers in endovascular therapy were applied in the endovenous laser ablation for treating saphenous insufficiency [9]. Onlabel indications of excimer laser angioplasty (ELA) in peripheral artery disease (PAD), specifically in-stent restenosis [10] and non-crossable chronic occlusions [11], have appeared. More recently, other off-label indications have emerged for material ablation and fabric welding to perform in situ fenestration of aortic endografts [12]

The main laser used in arterial surgery is the excimer laser using the photoablative laser's characteristics. An excimer laser is produced by a high-energy voltage associated with a dimeric solution of xenon and hydrochloride. The high-voltage energy excites the dimer $\mathrm{XeCl}$ and creates a photon. The laser is conducted by optic fibers, at a wavelength of $308 \mathrm{~nm}$ located in the blue spectrum. Whereas many other lasers deliver their energy in the warm red spectrum, the excimer laser is a cold laser. This last characteristic allows vascular surgeons and interventionalists to use excimer laser with a theoretical low risk of thrombus formation or deterioration of the arterial wall. The light penetration depth is around $0.05 \mathrm{~mm}$, and each photon carries enough energy to break a single carbon-carbon bond. Intracellular lipids and proteins absorb this high energy and are quickly destroyed. Finally, all the intracellular liquid is vaporized. Microscopic subcellular debris are created and washed distally with a theoretical benefit in terms of clinic emboli.

Whereas the first lasers were continuous-wave lasers, the excimer laser delivers its energy by pulse to avoid the heat diffusion from the catheter tip and the damage of surrounding tissues.

Each catheter conducts its energy from a generator to the catheter tip, composed of multiple optic fibers arranged around a guidewire lumen. Different diameters of the catheter exist according to the surgical applications, from $0.9 \mathrm{~mm}$ to $2.5 \mathrm{~mm}$. Settings (Fluence $(\mathrm{mJ} / \mathrm{mm} 2)$ and rate $(\mathrm{Hz})$ ) can be modified per the power needed. In fact, for calcified lesions or occlusions, the average power should be increased to obtain a maximum debulking. 
83 Two types of devices are commercially available. First, Turbo-Tandem (TT) (previous generation: Turbo-

84 Booster (TB)/ CliRpath) (Spectranetics, Colorado Springs, CO, USA) is a laser-guided catheter combined with a 85 laser atherectomy catheter, whereas Turbo-Elite (TE) (Spectranetics, Colorado Springs, CO, E-U) is just a laser 86 atherectomy catheter. TT is preferred for diameters of target arteries over $5 \mathrm{~mm}$ or to obtain maximum 87 debulking. Both devices progress on the wire after crossing the lesion or with a "step-by-step technique". A 88 speed progression of the catheter of $1 \mathrm{~mm} / \mathrm{s}$ is advised to be more effective.

89 The aim of this study is to review the different therapeutics applications of excimer lasers in endovascular 90 therapy.

91

92 


\section{METHODS}

94

95 A literature's review was performed using of the Preferred Reporting Items for Systematic Reviews and Meta-

96 Analysis (PRISMA) guidelines [13] Figure.

\section{Search Strategy}

98 We reviewed the English-language literature regarding the use of excimer laser on several medical databases:

99 Medline databases using a PubMed interface, the Cochrane Database, Web of Science, and Scopus. The search period was from June 2005 to May 2017. We used the key words "Excimer Laser", "in stent restenosis," "in situ

101 fenestration."

102 Study Selection

103 Studies were included if they met the following criterion: laser uses in arterial disease including PAD and aortic 104 or visceral procedures.

105 Clinical and experimental papers were studied. Only published data were included in this study. Two 106 independent analysts (J.J. and R.C.) selected and further analyzed 106 relevant papers. We excluded unrelated 107 papers ( $n=67)$, letters and commentaries $(n=6)$ and review articles $(n=7)$. Finally, 26 articles were included in 108 the qualitative synthesis.

\section{Data extraction}

110 Data were extracted regarding the type of paper (clinical or experimental and case report or case series) and 111 summarized using data extraction sheets. Relevant data were considered: on-label or off-label indications, 112 number of subjects, device used (TE, TT or TB, or both), demographics, technical success, in situ fenestration 113 type (retrograde or anterograde), in situ fenestration technique (catheter's diameter, graft type), technical success 114 rate, and early and late results (primary patency, target lesion revascularization). Data were managed using three 115 independent analyses: atherosclerotic plaques, in-stent restenosis, and off-label indications. 
RESULTS

119

120

121

122

123

124

125

126

127

128

129

130

131

132

133

134

135

136

137

138

139

140

141

142

143

144

145

146

147

In selected articles, TE catheters were used in 1,107 cases (79\%) [14-28], whereas TT or TB $[10,15,17,19,21,22,24,26,29]$ devices were used in 230 cases $(16 \%)$, and CliRpath (first laser-guided catheter generation) was used in 51 cases $(5 \%)$ [11].

A total of 18 articles were included in the analysis of the applications of ELA in PAD. The main objectives and results of treatment of atherosclerotic plaques and in-stent restenosis are respectively shown in Tables $\mathbf{1}$ and 2. Eight other articles described off-label" excimer laser indications in endovascular therapy, including five papers regarding in situ fenestrations for complex aortic aneurysms.

\section{Atherosclerotic plaques}

Nine articles $[11,14,15,17,21,25,27-29]$ related to atherosclerotic plaques were found. A total of 847 atherosclerotic plaques were treated, and $783 \mathrm{TE}(88 \%)$ and $104 \mathrm{TT}$ or TB (12\%) devices were used. Rastan et al. and Wu et al. both included in stent restenosis and atherosclerotic plaques. CliRpath device was used for 51 revascularizations. Among the nine articles, four included femoropopliteal lesions [15,21,27,29]. Sultan et al. included infra popliteal lesions, and the four last authors included femoropopliteal, infra popliteal, and combined lesions $[11,14,17,28]$, respectively. Five articles specified the lesion length [14,15,21,25,27]. Mean lesion length treated was $13.3 \pm 4.6 \mathrm{~cm}$. ELA was associated with percutaneous transluminal angioplasty (PTA)in $58 \% \pm 37 \%$ of cases. Stent implantation was performed in $29 \% \pm 28 \%$ of cases. Wu et al. compared spot stenting versus systematic stenting after ELA, and stenting was performed in $91 \%$ of cases. They concluded that primary stenting resulted in a longer primary patency rates at one year. Sultan et al. described the ELA technique for lower-limb arteries, and only $35 \%$ of the patients were treated by combined treatment ELA and stenting. No drug-eluting balloons were used for de novo arteries lesions.

Primary patency rates were available in five articles $[14,15,17,21,27]$. At $15 \pm 7$ months, mean primary patency rate was $65 \% \pm 20 \%$.

Mean distal embolism rate of four articles during the procedure was $5 \%[15,21,25,29]$.

\section{In-stent restenosis}

Regarding in-stent restenosis, inclusions criteria were met in eight articles [10,18-20,22-24,26]. A total of 427 femoropopliteal lesions were treated, and 316 TE (42\%) devices and 123 TB or TT (58\%) were used. Mean 
lesion length treated was $17.5 \pm 4.1 \mathrm{~cm}$. The mean technical success was $98 \%$, and mean rate of distal embolism during the procedure was $9 \%$. ELA was systematically evaluated in combination with another treatment. Three studies combined ELA technique with drug-eluting balloons [18,20,23], four associated ELA with PTA [19,22,24,26], and the SALVAGE study [19] describe results of ELA followed by covered stenting.

Primary patency rates were available in six articles [10,18,20,22-24]. At 10 \pm 4 months, mean primary patency rate was $68 \% \pm 18 \%$.

Finally, a clinical investigation focused on distal embolic events using ELA in 28 peripheral vascular lesions. A distal protection filter was deployed before laser therapy to recover debris produced by laser atherectomy. They highlighted $20 \%$ rate of clinically significant macrodebris [16].

\section{Off-label indications}

Among the eight selected articles regarding off-label indications, five were related to in situ fenestration of aortic endografts $[12,30-33]$.

Seventy in situ laser fenestrations were performed, and results are described in Table 3. The main objective was to perform a retrograde fenestration from the left subclavian artery to a thoracic aortic endograft during emergency endovascular treatment of a thoracic aortic aneurysm. A total of 35 Talent endograft, 8 Gore TAG, 3 Cook TX2 and 2 LifeTech Scientific Corp. were fenestrated using the TE catheter or Lasemar catheter. Laser catheter diameter varied between 2.0 and $2.5 \mathrm{~mm}$. Three authors specified that the contact between the endograft and the catheter tip was around 3 to 5 s $[30,31,33]$. Two type II endoleak from the left subclavian artery, which was successfully treated by coil embolization were reported. Concerning the four clinical evaluations, the primary patency rate was $100 \%$ after $9 \pm 1$-month follow-up. In the largest clinical study, technical success was achieved in $95.8 \%$ of cases [33]. An experimental study on pigs regarding embolism after anterograde fenestration of textile polyester stent grafts using a $2 \mathrm{~mm}$ TE catheter was performed. They concluded that the technique does not produce macroscopically visible emboli or clot.

Three articles described other off-label excimer laser indications in endovascular therapy. First, Chander et al. [34] reported a case series of 4 recanalizations of failed autogenous saphenous vein graft using laser revascularization. A 0.9 to 1.7 TE laser catheter was used with $100 \%$ technical success. Second, Topaz et al. [35] described a retrospective review of excimer laser debulking of 12 lesions unsuitable for standard renal angioplasty. The laser debulking using a 0.9 to $2 \mathrm{~mm}$ TE catheter was followed by renal artery stenting. No laser-induced complications and no controlled angiographic renal artery stenosis occurred. Finally, a case of 
178 excimer laser use to treat a severe central venous lesion downstream to an arterio-venous access was reported

179 [36]. A $2 \mathrm{~mm}$ TE catheter was introduced in the right subclavian vein followed by an $8 \mathrm{~mm}$ high pressure

180 balloon angioplasty.

181 


\section{DISCUSSION}

183

184 This work aimed to review the use of excimer laser in PAD and in other off-label indications such as in situ 185 fenestration of aortic endografts.

186

187 The excimer Laser was first used for coronary revascularization specifically for treating in stent restenosis and atherectomy $[37,38]$. Other cardiologic applications such as transvenous extraction of implanted pacemakers and implantable cardioverter-defibrillator leads have emerged [39]. Neurosurgeons and neuroradiologists have also used this technology and developed a new technique called excimer laser-assisted non-occlusive anastomosis to perform anastomosis on intracerebral arteries and have reported encouraging results [40]. The large size of the devices and difficulty implementing them limited laser use for medical indications; miniaturization has allowed laser technology to develop and for the number of applications in medical and surgical use to increase.

194 The ELA procedure represents an alternative for treating in-stent restenosis and atherosclerotic plaques [16].

195 Neither significant arterial perforation nor saphenous nerve injury were reported. However, short and mid-term primary patency rates were available for only 11 articles among the 18 articles included in the analysis of ELA in PAD. Besides, bail out stenting was frequently needed in the treatment of atherosclerotic plaques because of local dissections following catheter crossing.

199 Embolization rates were substantial following an ELA procedure. Our analysis highlights a 5\% and 9\% embolization rate following ELA in atherosclerotic plaques and in stent restenosis treatment, respectively. Specifically, the DEEPEMBOLI registry assessed the presence of embolic debris following ELA using systematic distal filter [16]. A concerning rate of $20 \%$ of macrodebris was found. The authors suspected ELA treatment of complex atherosclerotic lesions and suboptimal debulking as risk factors for distal embolization

204 [16]. This raises the question of systematic distal filter protection during ELA procedure.

205 In-stent restenosis rates due to myointimal hyperplasia reach up to 50\% [41,42]. Several treatments, such as 206 cutting balloons, directional atherectomy, and drug-eluting balloons, have been evaluated to cure myointimal hyperplasia. Some authors have prospectively studied, the treatment of in-stent restenosis using paclitaxeleluting balloon angioplasty. After 1 year, the primary patency rate was $83.7 \%$ with a reintervention rate of $9.8 \%$ [43]. The excimer laser allows recalibrating the vessel lumen in the stent by destroying fibrous material. ELA was associated with adjunctive therapy, such as drug-eluting balloons, provides satisfactory results [20], but this 
212 indications of ELA have emerged, mainly laser in situ fenestration of aortic endografts. Laser technology is an 213 alternative to mechanical technique using transseptal needles or stiff guidewires [46]. Recently, it was stressed 214 that needles compared to laser catheters were not flexible enough to enter a directional sheath, thereby limiting their use for anterograde in situ fenestrations [47]. Laser in situ fenestration consists of puncturing the endograft

216 with the laser catheter angled by steerable sheath, enlarging the hole created if necessary and stabilizing the fenestration by covered or uncovered stent. The successful treatment of a proximal type 1 Endoleak using an 218 Endurant aortic cuff with triple antegrade in situ fenestration was recently reported [48]. However, the choice of the best graft and the impact of laser fenestration on textile remain unknown. More experimental studies must be conducted to assess biomechanical textile modification and long-term effects following laser fenestration, for the latter to become an "on-label technique."

222 ELA's cost-effectiveness is yet to be demonstrated and remains a global concern. In our country, TE's price reaches $1900 €$ (approx. 2,200US\$) for the catheter and $175000 €$ (approx. 204,000US\$) for the CVX 300 generator (taxes not included). Combined with adjunctive therapy such, as drug-eluting balloons, stenting, and perclose systems, the cost of ELA procedures can become extremely high. This may limit ELA diffusion [49]. Finally, reported results of the excimer laser open prospects for new applications such as arteriovenous accesses management. Venous stenosis caused by myointimal hyperplasia lead to high rates of reinterventions that could be simplified by laser use. Similarly, in situ fenestration was frequently performed using textile polyester endograft, but polytetrafluoroethylene (PTFE) endograft testing could be relevant to get away the fenestration from filament textile deterioration and extend the indication to the endovascular treatment of femoral bifurcation and popliteal occlusive disease.

232 


\section{CONCLUSION}

246

247 The number of excimer laser applications is increasing. Laser technology represents a physical alternative to 248 current mechanical means to treat various arterial diseases. Limitations include a concerning intra-operative 249 embolism rate when treating PAD and a high cost. Long-term results and prospective comparative studies are 250 lacking to validate the excimer laser as standard use in endovascular therapy.

254 Acknowledgments : We thank the "Société Française de chirurgie vasculaire et endovasculaire" (SCVE), the 255 "Association chirurgicale pour le développement et l'Amélioration des techniques de Dépistage et de Traitement 256 des maladies Cardiovasculaires" (ADETEC), and the "Association pour la Recherche et la Formation 257 Chirurgicale en Ile de France » (ARFCIDF) for providing funding for this study. 


\section{REFERENCES:}

263

264 [1]. Mlacker S, Shah VV, Aldahan AS, McNamara CA, Kamath P, Nouri K. Laser and light-based 265 treatments of venous lakes: a literature review. Lasers Med Sci. 2016 Sep;31:1511-9.

266 [2]. Sjogren PP, Sidman JD. Use of the carbon dioxide laser for tracheobronchial lesions in children. JAMA 267 Otolaryngol-- Head Neck Surg. 2013 Mar;139:231-5.

268 [3]. Davoudi A, Sanei M, Badrian H. Application of Laser Irradiation for Restorative Treatments. Open 269 Dent J. 2016;10:636-42.

270 [4]. Gupta PK. Is the holmium:YAG laser the best intracorporeal lithotripter for the ureter? A 3-year 271 retrospective study. J Endourol. 2007 Mar;21:305-9.

272 [5]. Park Y-K, Park C-H. Clinical efficacy of photodynamic therapy. Obstet Gynecol Sci. 2016 273 Nov;59:479-88.

274 [6]. Otsuji T, Sho K, Tsumura A, Koike N, Nishimura T, Takahashi K. Three-year results of a modified 275 photodynamic therapy procedure (Ironing PDT) for age-related macular degeneration patients with large lesions.

276 Clin Ophthalmol Auckl NZ. 2016;10:431-6.

277 [7]. Cochennec F, Kobeiter H, Gohel M, Leopardi M, Raux M, Majewski M, et al. Early Results of 278 Physician Modified Fenestrated Stent Grafts for the Treatment of Thoraco-abdominal Aortic Aneurysms. Eur J 279 Vasc Endovasc Surg. 2015 Nov;50:583-92.

280 [8]. Al Khoury G, Chaer R. Evolution of atherectomy devices. J Cardiovasc Surg (Torino). 2011 281 Aug;52:493-505.

282 [9]. Jibiki M, Miyata T, Futatsugi S, Iso M, Sakanushi Y. Effect of the wide-spread use of endovenous laser 283 ablation on the treatment of varicose veins in Japan: a large-scale, single institute study. Laser Ther. 2016 Oct $284 \quad 1 ; 25: 171-7$.

285 [10]. Laird JR, Yeo KK, Rocha-Singh K, Das T, Joye J, Dippel E, et al. Excimer laser with adjunctive 286 balloon angioplasty and heparin-coated self-expanding stent grafts for the treatment of femoropopliteal artery in287 stent restenosis: twelve-month results from the SALVAGE study. Catheter Cardiovasc Interv. 2012 Nov $288 \quad 1 ; 80: 852-9$.

289 [11]. Bosiers M, Peeters P, Elst FV, Vermassen F, Maleux G, Fourneau I, et al. Excimer laser assisted 290 angioplasty for critical limb ischemia: results of the LACI Belgium Study. Eur J Vasc Endovasc Surg. 2005 291 Jun;29:613-9. 
292 [12]. Murphy EH, Dimaio JM, Dean W, Jessen ME, Arko FR. Endovascular repair of acute traumatic 293 thoracic aortic transection with laser-assisted in-situ fenestration of a stent-graft covering the left subclavian 294 artery. J Endovasc Ther. 2009 Aug;16:457-63.

295 [13]. Liberati A, Altman DG, Tetzlaff J, Mulrow C, Gøtzsche PC, Ioannidis JPA, et al. The PRISMA 296 statement for reporting systematic reviews and meta-analyses of studies that evaluate healthcare interventions: 297 explanation and elaboration. BMJ. 2009 Jul 21;339:b2700.

298 [14]. Zhou W, Bush RL, Lin PH, Peden EK, Lumsden AB. Laser atherectomy for lower extremity 299 revascularization: An adjunctive endovascular treatment option. Vasc Endovascular Surg. 2006 Sep;40(4):26830074.

301 [15]. Dave RM, Patlola R, Kollmeyer K, Bunch F, Weinstock BS, Dippel E, et al. Excimer laser 302 recanalization of femoropopliteal lesions and 1-year patency: results of the CELLO registry. J Endovasc Ther. 3032009 Dec;16:665-75.

304 [16]. Shammas NW, Coiner D, Shammas GA, Christensen L, Dippel EJ, Jerin M. Distal embolic event 305 protection using excimer laser ablation in peripheral vascular interventions: results of the DEEP EMBOLI 306 307 308 309 registry. J Endovasc Ther. 2009 Apr;16:197-202.

[17]. Serino F, Cao Y, Renzi C, Mascellari L, Toscanella F, Raskovic D, et al. Excimer laser ablation in the treatment of total chronic obstructions in critical limb ischaemia in diabetic patients. Sustained efficacy of plaque recanalisation in mid-term results. Eur J Vasc Endovasc Surg. 2010 Feb;39:234-8.

[18]. Van Den Berg JC, Pedrotti M, Canevascini R, Chimchila Chevili S, Giovannacci L, Rosso R. Endovascular treatment of in-stent restenosis using excimer laser angioplasty and drug eluting balloons. J Cardiovasc Surg (Torino). 2012 Apr;53:215-22.

[19]. Shammas NW, Shammas GA, Hafez A, Kelly R, Reynolds E, Shammas AN. Safety and One-Year revascularization outcome of excimer laser ablation therapy in treating in-stent restenosis of femoropopliteal arteries: A retrospective review from a single center. Cardiovasc Revascularization Med Mol Interv. 2012 Dec;13:341-4.

[20]. Gandini R, Del Giudice C, Merolla S, Morosetti D, Pampana E, Simonetti G. Treatment of chronic SFA in-stent occlusion with combined laser atherectomy and drug-eluting balloon angioplasty in patients with critical limb ischemia: a single-center, prospective, randomized study. J Endovasc Ther. 2013 Dec;20:805-14.

[21]. Wu T-Y, Chou H-H, Chang S-H, Tsai Y-J, Hsieh C-A, Cheng S-T, et al. Comparison of immediate and 2-year outcomes between excimer laser-assisted angioplasty with spot stent and primary stenting in intermediate 
322 to long femoropopliteal disease. ScientificWorldJournal. 2013;2013:247102.

323 [22]. Schmidt A, Zeller T, Sievert H, Krankenberg H, Torsello G, Stark MA, et al. Photoablation using the 324 turbo-booster and excimer laser for in-stent restenosis treatment: twelve-month results from the PATENT study. 325 J Endovasc Ther. 2014 Feb;21:52-60.

326 [23]. Van Den Berg JC, Pedrotti M, Canevascini R, Chimchila Chevili S, Giovannacci L, Rosso R. In-stent restenosis: mid-term results of debulking using excimer laser and drug-eluting balloons: sustained benefit? J

328 Invasive Cardiol. 2014 Jul;26:333-7.

329 [24]. Dippel EJ, Makam P, Kovach R, George JC, Patlola R, Metzger DC, et al. Randomized controlled study 330 of excimer laser atherectomy for treatment of femoropopliteal in-stent restenosis: initial results from the 331 EXCITE ISR trial (EXCImer Laser Randomized Controlled Study for Treatment of FemoropopliTEal In-Stent 332 Restenosis). JACC Cardiovasc Interv. 2015 Jan;8:92-101.

333 [25]. Sultan S, Tawfick W, Hynes N. Cool excimer laser-assisted angioplasty (CELA) and tibial balloon 334 angioplasty (TBA) in management of infragenicular arterial occlusion in critical lower limb ischemia (CLI). 335 Vasc Endovascular Surg. 2013 Apr;47:179-91.

336 [26]. Armstrong EJ, Thiruvoipati T, Tanganyika K, Singh GD, Laird JR. Laser Atherectomy for Treatment of 337 Femoropopliteal In-Stent Restenosis. J Endovasc Ther. 2015 Aug;22:506-13.

338 [27]. Wissgott C, Kamusella P, Lüdtke C, Andresen R. Excimer laser atherectomy after unsuccessful 339 angioplasty of TASC C and D lesions in femoropopliteal arteries. J Cardiovasc Surg (Torino). 2013 Jun;54:35934065.

341 [28]. Mallios A, Blebea J, Buster B, Messiner R, Taubman K, MA H. Laser atherectomy for the treatment of 342 peripheral arterial disease. Ann Vasc Surg. 2017;

343 [29]. Rastan A, Sixt S, Schwarzwälder U, Kerker W, Bürgelin K, Frank U, et al. Initial experience with 344 directed laser atherectomy using the CLiRpath photoablation atherectomy system and bias sheath in superficial 345 femoral artery lesions. J Endovasc Ther. 2007 Jun;14:365-73.

346 [30]. Ahanchi SS, Almaroof B, Stout CL, Panneton JM. In situ laser fenestration for revascularization of the 347 left subclavian artery during emergent thoracic endovascular aortic repair. J Endovasc Ther. 2012 Apr;19:22634830.

349 [31]. Redlinger RE, Ahanchi SS, Panneton JM. In situ laser fenestration during emergent thoracic 350 endovascular aortic repair is an effective method for left subclavian artery revascularization. J Vasc Surg. 2013 351 Nov;58:1171-7. 
352 [32]. Sonesson B, Dias N, Resch T, Kristmundsson T, Holst J. Laser Generated In situ Fenestrations in 353 Dacron Stent Grafts. Eur J Vasc Endovasc Surg. 2016 Apr;51:499-503.

354 [33]. Qin J, Zhao Z, Wang R, Ye K, Li W, Liu X, et al. In Situ Laser Fenestration Is a Feasible Method for 355 Revascularization of Aortic Arch During Thoracic Endovascular Aortic Repair. J Am Heart Assoc. 2017 Apr $35621 ; 6$

357 [34]. Chander RK, Oza P, Patel M, Balar N. Recanalization of failed autogenous conduit utilizing laser 358 revascularization. Vasc Endovascular Surg. 2011 Oct;45:636-40.

359 [35]. Topaz O, Polkampally PR, Topaz A, Polkampally CR, Jara J, Rizk M, et al. Utilization of excimer laser 360 debulking for critical lesions unsuitable for standard renal angioplasty. Lasers Surg Med. 2009 Nov;41:622-7.

361 [36]. Yevzlin AS, Urbanes A. Excimer laser assisted angioplasty in hemodialysis access intervention. Semin 362 Dial. 2009 Oct;22:580-3.

363 [37]. Hirose S, Ashikaga T, Hatano Y, Yoshikawa S, Sasaoka T, Maejima Y, et al. Treatment of in-stent 364 restenosis with excimer laser coronary angioplasty: benefits over scoring balloon angioplasty alone. Lasers Med 365 Sci. 2016 Nov;31:1691-6.

366 [38]. Ollivier JP, Avrillier S, Rougier J, Raynal E, Gandjbakhch I, Berthier JP, et al. [Contribution of excimer 367 laser to coronary angioplasty]. Arch Mal Coeur Vaiss. 1988 Mar;81:261-7.

368 [39]. Okamura H, Yasuda S, Sato S, Ogawa K, Nakajima I, Noda T, et al. Initial experience using Excimer 369 laser for the extraction of chronically implanted pacemaker and implantable cardioverter defibrillator leads in 370 Japanese patients. J Cardiol. 2013 Sep;62:195-200.

371 [40]. Bremmer J, van Doormaal TPC, Verweij BH, van der Zwan A, Tulleken CAF, Verdaasdonk R. Vessel 372 wall perforation mechanism of the excimer laser-assisted non-occlusive anastomosis technique. Lasers Med Sci. 3732016 Aug;31:1169-75.

374 [41]. Del Giudice C, Gandini R, Simonetti G. Atherectomy for superficial femoral artery in-stent restenosis: 375 can lasers light the way to a better outcome? J Endovasc Ther. 2014 Apr;21:356-8.

376 [42]. Kornowski R, Hong MK, Tio FO, Bramwell O, Wu H, Leon MB. In-stent restenosis: contributions of 377 inflammatory responses and arterial injury to neointimal hyperplasia. J Am Coll Cardiol. 1998 Jan;31:224-30.

378 [43]. Bague N, Julia P, Sauguet A, Pernès JM, Chatelard P, Garbé JF, et al. Femoropopliteal In-stent 379 Restenosis Repair: Midterm Outcomes After Paclitaxel Eluting Balloon Use (PLAISIR Trial). Eur J Vasc 380 Endovasc Surg. 2017 Jan;53:106-13.

381 [44]. Shammas NW, Shammas GA, Jerin M. Differences in patient selection and outcomes between 
382 SilverHawk atherectomy and laser ablation in the treatment of femoropopliteal in-stent restenosis: a 383 retrospective analysis from a single center. J Endovasc Ther. 2013 Dec;20:844-52.

384 [45]. Ducasse E. Economic Evaluation Comparing Standard Balloon Angioplasty Versus Drug-eluted 385 Balloon or Laser-Excimer in Association With Drug-eluted Balloon in the Treatment of Femoropopliteal Artery 386 In-stent Restenosis. NCT02599389.

387 [46]. Coscas R, Glorion M, Javerliat I, Goëau-Brissonniere O, Coggia M. In Situ Fenestration Through the 388 Contralateral Iliac Artery to Convert an Aortouni-iliac Into a Bifurcated Endograft. J Endovasc Ther Off J Int 389 Soc Endovasc Spec. 2015 Jun;22:421-5.

390 [47]. Glorion M, Coscas R, McWilliams RG, Javerliat I, Goëau-Brissonniere O, Coggia M. A 391 Comprehensive Review of In Situ Fenestration of Aortic Endografts. Eur J Vasc Endovasc Surg. 2016 392 Dec;52:787-800.

393 [48]. Touma J, Kobeiter H, Majewski M, Tacher V, Desgranges P. Cardiovasc Intervent Radiol. 2018 394 Mar;41(3):513-517.

395 [49]. Shishehbor MH, Jaff MR. Percutaneous Therapies for Peripheral Artery Disease. Circulation. 2016 Dec $396 \quad 13 ; 134: 2008-27$.

397

398

399

400

401 


\section{LEGENDS :}

403

404 Table 1: Tabular review of paper regarding de novo lesions treatment using ELA

405 PP: Primary patency, TLR: Target lesion revascularization, CLI: critical limb ischemia, FP: Femoropopliteal,

406 ABI: Ankle brachial index, DEB: Drug eluted balloon, TBA: Tibial balloon angioplasty, NA: Not available,

407 applicable

408

409 Table 2: Tabular review of paper regarding in stent restenosis treatment using ELA

410 PP: Primary patency, TLR: Target lesion revascularization, TVR: Target vessel revascularization, FPISR:

411 Femoropopliteal in stent restenosis, ABI: Ankle brachial index, DEB: Drug eluted balloon, PTA: Percutaneous

412 transluminal angioplasty, NA: Not available, applicable

413

414 Table 3: Tabular review of paper regarding laser in situ fenestration

415 LSCA: Left Subclavian artery, TEVAR: Thoracic endovascular aneurysm repair, ISF: in situ fenestration, PP:

416 Primary Patency, NA: Not available, applicable

417

418 Figure : Flow chart depicting articles selection for the current review according to the PRISMA (Reporting

419 Items for Systematic Reviews and Meta-Analysis) guidelines.

420

421

422 
Records identified through database searching $(n=106)$

Records screening ( $n=106)$

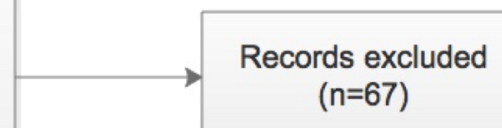

Full-text articles assessed for eligibility $(n=39)$

Studies included in qualitative synthesis $(n=26)$ 


\begin{tabular}{|c|c|c|c|c|c|c|c|c|}
\hline \multirow[b]{2}{*}{ Reference } & \multirow[b]{2}{*}{ Main objective } & \multirow[b]{2}{*}{ Study Design } & \multicolumn{6}{|c|}{ Results } \\
\hline & & & $\begin{array}{c}\mathrm{N} \\
\text { (Lesions) }\end{array}$ & $\begin{array}{l}\text { Technical } \\
\text { success } \\
(\%)\end{array}$ & $\begin{array}{l}\text { Follow- } \\
\text { up } \\
\text { (months) }\end{array}$ & $\mathbf{P P}(\%)$ & $\operatorname{TLR}(\%)$ & Others relevant results \\
\hline $\begin{array}{l}\text { Bosiers } \\
2005\end{array}$ & $\begin{array}{l}\text { Efficacy of Laser } \\
\text { angioplasty in CLI }\end{array}$ & $\begin{array}{l}\text { Prospective } \\
\text { multicentric }\end{array}$ & 51 & NA & 6 & NA & NA & $74 \%$ limb salvage \\
\hline Zhou 2006 & $\begin{array}{c}\text { Evaluate } \\
\text { effectiveness } \\
\text { ELA+PTA for CLI }\end{array}$ & $\begin{array}{c}\text { Retrospective } \\
\text { monocentric }\end{array}$ & 15 & 84 & 6 & 57 & NA & NA \\
\hline $\begin{array}{c}\text { Rastan } \\
2007\end{array}$ & $\begin{array}{c}\text { Safety and efficacy } \\
\text { of ELA bias sheath } \\
\text { catheter for SFA }\end{array}$ & $\begin{array}{l}\text { Prospective } \\
\text { monocentric }\end{array}$ & 6 & 79 & 1 & NA & NA & $\begin{array}{c}\text { ABI } 0.8 \text { increase and } \\
\text { Rutherford increase } 3 \text { points }\end{array}$ \\
\hline Dave 2009 & $\begin{array}{l}\text { Evaluate EL } \\
\text { recanalization for } \\
\text { FP lesions }\end{array}$ & $\begin{array}{l}\text { Prospective } \\
\text { multicentric }\end{array}$ & 65 & 100 & 6 and 12 & 59 and 54 & 23.1 (12 months) & NA \\
\hline $\begin{array}{c}\text { Serino } \\
2010\end{array}$ & $\begin{array}{l}\text { ELA for treatment } \\
\text { of CLI in diabetic } \\
\text { patients }\end{array}$ & $\begin{array}{l}\text { Prospective } \\
\text { monocentric }\end{array}$ & 51 & 88 & 12 and 24 & 97.6 and 82.7 & 13.4 and 17.3 & Limb salvage $100 \%$ and $94 \%$ \\
\hline $\begin{array}{c}\text { Wisgott } \\
2013\end{array}$ & $\begin{array}{l}\text { Application of ELA } \\
\text { for refractory FP } \\
\text { lesions }\end{array}$ & $\begin{array}{l}\text { Retrospective } \\
\text { monocentric }\end{array}$ & 40 & 90 & 12 & 58.9 & NA & $\begin{array}{c}\text { Primary assissted Patency and } \\
\text { Secondary assissted Patency } \\
67.8 \% \text { and } 83.2 \%\end{array}$ \\
\hline Wu 2013 & $\begin{array}{l}\text { ELA+Spot stent vs } \\
\text { ELA+systematic } \\
\text { stenting FP disease }\end{array}$ & $\begin{array}{l}\text { Retrospective } \\
\text { monocentric }\end{array}$ & 106 & 100 & 24 & $\begin{array}{l}25 \text { (ELA+spot } \\
\text { stent) vs } 45 \\
\text { (ELA+systematic } \\
\text { stenting) }(\mathrm{P}=.03) \\
\end{array}$ & $\begin{array}{c}65 \text { (ELA+spot } \\
\text { stent) vs } 45 \\
\text { (ELA+systematic } \\
\text { stenting) } \\
\end{array}$ & $\begin{array}{c}\text { Earlier restenosis } 67 \% \\
\text { (ELA+spot stent) vs } 32 \% \\
\text { (ELA+systematic stenting) } \\
(\mathrm{P}=.001)\end{array}$ \\
\hline $\begin{array}{c}\text { Sultan } \\
2013\end{array}$ & $\begin{array}{l}\text { Compare outcome } \\
\text { of CoolELA vs TA }\end{array}$ & $\begin{array}{l}\text { Retrospective } \\
\text { monocentric }\end{array}$ & 42 & 81 & 36 & NA & $\begin{array}{l}14.8 \% \text { (ELA) vs } \\
36.2 \text { (TBA) } \\
(\mathrm{P}=.873)\end{array}$ & $\begin{array}{c}\text { Sustained clinical improvement } \\
\text { ELA 81\% vs 63.8\% TBA } \\
\text { (P=.013), Amputation free- } \\
\text { survival 95.2\% ELA vs } \\
78.7 \% \text { TBA (P=.016) }\end{array}$ \\
\hline $\begin{array}{c}\text { Mallios } \\
2017\end{array}$ & $\begin{array}{l}\text { Clinical results of } \\
\text { laser atherectomy } \\
\text { in the treatment of } \\
\text { PAD }\end{array}$ & $\begin{array}{l}\text { Retrospective } \\
\text { monocentric }\end{array}$ & 471 & 99 & 28 & NA & 20 & $\begin{array}{c}\text { Freedom from major } \\
\text { amputation } 90 \% \text { at } 5 \text { years }\end{array}$ \\
\hline
\end{tabular}




\begin{tabular}{|c|c|c|c|c|c|c|c|c|}
\hline \multirow[b]{2}{*}{ Reference } & \multirow[b]{2}{*}{ Main objective } & \multirow[b]{2}{*}{ Study Design } & \multicolumn{6}{|c|}{ Results } \\
\hline & & & $\stackrel{\mathrm{N}}{\text { (lesions) }}$ & $\begin{array}{l}\text { Technical } \\
\text { success } \\
(\%)\end{array}$ & $\begin{array}{l}\text { Follow- } \\
\text { up } \\
\text { (months) }\end{array}$ & $\mathbf{P P}(\%)$ & $\operatorname{TLR}(\%)$ & Others relevant results \\
\hline Laird 2012 & $\begin{array}{l}\text { Evaluate treatment } \\
\text { FPISR with } \\
\text { ELA+viabahn }\end{array}$ & $\begin{array}{l}\text { Prospective } \\
\text { multicentric }\end{array}$ & 27 & 100 & 12 & 48 & 17.4 & $\mathrm{ABI}$ increased 0.58 to 0.9 \\
\hline $\begin{array}{l}\text { Shammas } \\
2012\end{array}$ & ELA+PTA FPISR & $\begin{array}{l}\text { Retrospective } \\
\text { monocentric }\end{array}$ & 40 & 93 & 12 & NA & 48.7 & TVR $48.7 \%$ \\
\hline $\begin{array}{c}\text { Van den Berg } \\
2012\end{array}$ & $\begin{array}{l}\text { ELA+DEB for } \\
\text { FPISR }\end{array}$ & $\begin{array}{l}\text { Restrospective } \\
\text { monocentric }\end{array}$ & 10 & 100 & 7.6 & 70 & 0 & $\begin{array}{l}\text { Mean time of occurrence } \\
\text { restenosis 7.2months }\end{array}$ \\
\hline Gandini 2013 & $\begin{array}{l}\text { ELA+DEB vs DEB } \\
\text { for SFA in stent } \\
\text { occlusion for CLI }\end{array}$ & $\begin{array}{l}\text { Prospective } \\
\text { monocentric }\end{array}$ & 24 & 100 & 6 and 12 & $\begin{array}{c}91.7 \text { and } 66.7 \\
(\mathrm{ELA}+\mathrm{DEB}) \mathrm{vs} \\
58.3 \text { and } 37.5 \\
(\mathrm{DEB})(\mathrm{P}=.01) \\
\end{array}$ & $\begin{array}{c}16.7 \%(\mathrm{ELA}+\mathrm{DEB}) \\
\text { vs } 50 \%(\mathrm{DEB}) \\
(\mathrm{P}=.01)\end{array}$ & NA \\
\hline Schmidt 2014 & $\begin{array}{c}\text { Evaluate } \\
\text { performance of TE } \\
\text { and TB for FPISR }\end{array}$ & $\begin{array}{l}\text { Prospective } \\
\text { multicentric }\end{array}$ & 90 & 96.7 & 6 and 12 & $\begin{array}{l}64.1 \text { (95CI 53- } \\
73.9) \text { and } 37.8 \\
\text { (95CI 27.7-49.2) }\end{array}$ & $\begin{array}{c}12.2(95 \mathrm{CI} 7-21) \\
\text { and } 35.5(95 \mathrm{CI} \\
17.6-59.4)\end{array}$ & NA \\
\hline $\begin{array}{l}\text { Van Den Berg } \\
2014\end{array}$ & $\begin{array}{l}\text { Evaluate midterm } \\
\text { follow-up } \\
\text { ELA+DEB FPISR }\end{array}$ & $\begin{array}{l}\text { Prospective } \\
\text { cohort }\end{array}$ & 14 & 100 & 19.4 & 91.7 & 7 & $\begin{array}{l}\text { Mean time of recurrence of } \\
\text { restenosis } 8.6 \text { months }\end{array}$ \\
\hline Dippel 2015 & $\begin{array}{l}\text { ELA+PTA vs PTA } \\
\text { alone for FPISR }\end{array}$ & $\begin{array}{l}\text { Multicentric } \\
\text { prospective } \\
\text { randomized }\end{array}$ & 168 & 93.5 & 6 & $\begin{array}{c}71.1 \text { (ELA+PTA) } \\
\text { vs } 56.4 \text { (PTA) }\end{array}$ & $\begin{array}{c}\text { 26.5(ELA+PTA) vs } \\
\text { 49(ELA) }(\mathrm{P}<.005)\end{array}$ & NA \\
\hline $\begin{array}{l}\text { Armstrong } \\
2015\end{array}$ & $\begin{array}{l}\text { ELA+PTA vs PTA } \\
\text { alone for FPISR }\end{array}$ & $\begin{array}{l}\text { Retrospective } \\
\text { multicentric }\end{array}$ & 54 & 100 & 24 & NA & $\begin{array}{c}14 \text { (ELA) vs } \\
44(\mathrm{PTA} \text { alone }) \\
(\mathrm{P}=.05)\end{array}$ & $\begin{array}{l}\text { Class III ISR treated with ELA: } \\
54 \% \text { recurrent stenosis vs } 91 \% \\
\text { PTA at 1year }(\mathrm{P}=.05)\end{array}$ \\
\hline
\end{tabular}




\begin{tabular}{|c|c|c|c|c|c|c|c|}
\hline Reference & Study Design & $\begin{array}{c}\text { Main } \\
\text { Objectives }\end{array}$ & $\begin{array}{c}\mathrm{N} \\
\text { (fenestration) }\end{array}$ & Localization & Type & $\begin{array}{c}\text { Follow- } \\
\text { up } \\
\text { (months) } \\
\end{array}$ & Results \\
\hline $\begin{array}{l}\text { Murphy } \\
2009\end{array}$ & Case Report & $\begin{array}{l}\text { Laser ISF after } \\
\text { TEVAR } \\
\text { covering LSCA }\end{array}$ & 1 & LSCA & Retrograde & 8 & No endoleaks/stent patent \\
\hline $\begin{array}{l}\text { Ahanchi } \\
2012\end{array}$ & Retrospective monocentric & $\begin{array}{l}\text { Laser ISF during } \\
\text { emergency } \\
\text { TEVAR } \\
\end{array}$ & 5 & LSCA & Retrograde & 8 & $\begin{array}{c}\text { PP } 100 \% \text { /no endoleak related } \\
\text { to fenestration }\end{array}$ \\
\hline $\begin{array}{l}\text { Redlinger } \\
2013\end{array}$ & Retrospective monocentric & $\begin{array}{l}\text { Laser ISF during } \\
\text { emergency } \\
\text { TEVAR }\end{array}$ & 22 & LSCA & Retrograde & 10 & PP 100\% / 2 type II endoleaks \\
\hline $\begin{array}{l}\text { Sonesson } \\
2016\end{array}$ & Experimental study on pigs & $\begin{array}{l}\text { Evaluate if Laser } \\
\text { ISF generate } \\
\text { emboli }\end{array}$ & 7 & Iliac & Antegrade & NA & $\begin{array}{l}\text { No produce macroscopically } \\
\text { visible emboli or clot }\end{array}$ \\
\hline Qin 2017 & $\begin{array}{l}\text { Experimental study on swine } \\
\text { and clinical retrospective } \\
\text { monocentric }\end{array}$ & $\begin{array}{c}\text { Laser ISF of } \\
\text { aortic arch } \\
\text { during TEVAR }\end{array}$ & $\begin{array}{l}6 \text { (swine) and } \\
31 \text { (human) }\end{array}$ & $\begin{array}{l}\text { Carotid and } \\
\text { LSCA }\end{array}$ & Retrograde & 10 & $\begin{array}{l}\text { No tearing of the fabric/ } \\
\text { Technically feasible/ PP } \\
100 \% / \text { No endoleaks }\end{array}$ \\
\hline
\end{tabular}

